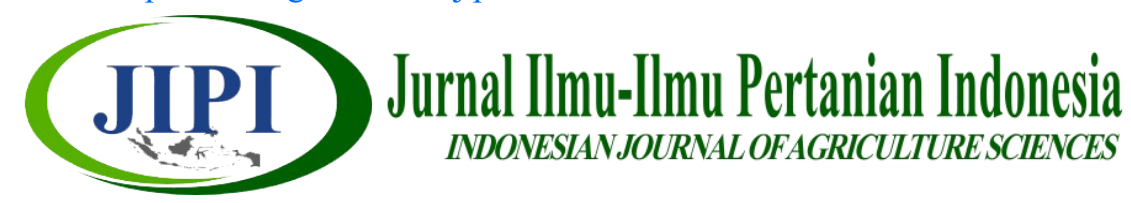

\title{
PENYAKIT ANTRAKNOSA CABAI OLEH Colletotrichum sp. DI LAHAN RAWA KALIMANTAN SELATAN
}

\author{
Mariana Mariana $^{1 *}$, Elly Liestiany ${ }^{1}$, Fahmi Rizali Cholis ${ }^{1}$, Nazwan Syahbani Hasbi ${ }^{1}$ \\ ${ }^{1}$ Prodi Proteksi Tanaman Fakultas Pertanian Universitas Lambung Mangkurat \\ Jalan Ahmad Yani Km. 36 Banjarbaru Kalimantan Selatan \\ *Corresponding Author: mariana@ulm.ac.id
}

\begin{abstract}
[CHILLI ANTHRACNOSE DISEASE BY Colletotrichum sp. AT SWAMP LAND OF SOUTH KALIMANTAN PROVINCE]. Anthracnose is one of the major economic constraints for chili production worldwide. This disease is caused by the fungus Colletotrichum sp. The yield loss reaches $50 \%-100 \%$ in the rainy season. In swamps, the incidence of this disease begins to increase. As the basis for the integrated control of anthracnose, it is necessary to record disease incidence and identify pathogens that attack conditions in swampsThe disease intensity survey was conducted in Hiyung chilli cultivation of Hiyung village lowland and the tidal swamplands of Marabahan district. The method is using Purposive Random Sampling approach. The Koch's Postulates is used to determined the cause of the disease. Identification of pathogens that cause anthracnose is carried out in laboratories and greenhouses. Determination of obtained pathogen's type is using literature references. The results of this study indicate that Hiyung chilli in the Hiyung village lowland shows a fairly high incidence of disease - i.e $45.59 \%$, moreover, the result of Marabahan district tidal swamplands is $57.54 \%$. Three Colletotrichum species were found, namely Colletotricum truncatum, C. gleosporiedes and C. acutatum.
\end{abstract}

Keyword: Anthracnose, Colletotrichum, chili, swampland

\begin{abstract}
ABSTRAK
Penyakit antraknosa adalah salah satu kendala ekonomi utama untuk produksi cabai di seluruh dunia. Penyakit ini disebabkan oleh jamur Colletotrichum sp. Kehilangan hasil mencapai 50\% - 100\% pada musim hujan. Kejadian penyakit ini mulai meningkat di lahan rawa. Sebagai dasar pengendalian terpadu penyakit antraknosa, perlu dilakukan pendataan kejadian penyakit, identifikasi patogen yang menyerang pada kondisi di lahan rawa. Survei intensitas penyakit dilakukan di pertanaman cabai Hiyung lahan rawa lebak Desa Hiyung dan di lahan rawa pasang surut Kecamatan Marabahan. Pengambilan sampel ditentukan berdasarkan Purposive Random Sampling Untuk menentukan penyebab penyakit mengikuti Postulat Koch. Identifikasi pathogen penyebab antraknosa dilakukan di laboratorium dan rumah kaca Penentuan jenis pathogen yang didapat, menggunakan rujukan pustaka. Hasil penelitian ini menunjukkan bahwa cabai rawit hiyung di lahan rawa lebak desa Hiyung menunjukkan insidensi penyakit yang cukup tinggi yaitu $45.59 \%$ dan di lahan rawa pasang surut kecamatan Marabahan sebesar $57.54 \%$. Ditemukan tiga spesies Colletotrichum yaitu Colletotricum truncatum, C. gleosporiedes dan C. acutatum
\end{abstract}

Kata kunci: Antraknosa, Colletotrichum, cabai, lahan rawa 


\section{PENDAHULUAN}

Penyakit antraknosa adalah salah satu kendala ekonomi utama untuk produksi cabai di seluruh dunia Penyakit busuk buah ini disebabkan oleh jamur Colletotrichum sp. Kehilangan hasil mencapai 50\% - 100\% pada musim hujan (Semangun, 2007; Than, 2008; Saxena et al., 2016; Diao et al., 2017; Widodo \& Hidayat, 2018; Silva et al., 2019).

Penyakit antraknosa di lahan rawa berpotensi menyebar melalui aliran air. Lahan rawa adalah lahan yang secara alami tergenang air (Susilawati \& Nazemi, 2017). Pada lahan rawa pasang surut, genangan tersebut terjadi sebagai akibat pengaruh aliran pasang surut air laut. Pada lahan rawa lebak genangan terjadi akibat curah hujan atau air kiriman dari daerah hulu sungai.. Keunggulan spesifik lahan rawa lebak antara lain dapat diusahakan sebagai lahan pertanian saat musim kemarau, pada saat agroekosistem lain mengalami kekeringan. Oleh karena itu, tanaman cabai di rawa lebak dapat ditanam off season di luar musim, sehingga harga jual lebih tinggi. Penanaman cabai di lahan rawa lebak, biasanya dilakukan di atas tukungan dengan sistem surjan. Pertanaman cabai terdapat pada lahan tipe B yang luapan air pasang hanya terjadi pada saat pasang besar (Raihana \& Kusrini, 2017). Pembebasan dan penyebaran konidia C. gloeosporioides melalui percikan dan mekanisme pencucian konidia selama hujan. Percikan_air memindahkan inokulum ke bagian tanaman lain. Pencucian menyebabkan konidia terdeposit di tanah. Aliran air di lapangan mengakibatkan inokulum terdistribusi ke seluruh lahan (Rajasab \& Chawda, 1994). Adanya genangan air seperti di lahan rawa berpotensi mempengaruhi kejadian penyakit antraknosa. Menurut Singh \& Pandey (2014) pengairan dengan irigasi tetes mengurangi kejadian penyakit antraknosa pada cabai empat kali lipat dibanding digenangi air.Dengan demikian adanya aliran air pada permukaan lahan pada saat air pasang dan surut, adanya hujan dan kiriman air pada lahan lebak berpotensi untuk penyebaran dan perkembangan penyakit antraknosa pada tanaman cabai

Lahan rawa lebak desa Hiyung merupakan sentra pertanaman cabai rawit lokal yang dikenal dengan cabai rawit banjar atau cabai Hiyung. Plasma nutfah ini telah resmi terdaftar pada Pusat Perlindungan Varietas Tanaman dan Perizinan Pertanian Kementerian Pertanian Republik Indonesia Nomor 09/ PLV/2012 tanggal 12 April 2012 sebagai varietas lokal dengan nama Cabai Rawit Hiyung. Cabai ini berasal dari desa Hiyung yang terletak di dataran rendah di Kabupaten Tapin Kalimantan Selatan. mempunyai keunggulan karena mempunyai tingkat kepedasan yang tinggi dengan kadar capcaisin 699,87 ppm. dan mempunyai daya simpan yang cukup lama (10-16 hari pada suhu ruangan) (Pramudyani, 2014). Petani lahan rawa lebak di Desa Hiyung hanya menanam cabai rawit Hiyung sepanjang musim, Cabai ditanam di atas tukungan dengan sistem surjan

Pengendalian penyakit antraknosa di tingkat petani masih mengandalkan fungisida kimia yang kalau tidak dilakukan dengan bijaksana akan menimbulkan banyak dampak negatif. Pengendalian yang dianjurkan adalah menggunakan pengendalian terpadu berbasis lingkungan. Sebagai langkah awalnya perlu dilakukan identiifikasi patogen penyebab antraknosa tesebut. Menurut Liu et al. (2016) antraknosa pada cabai di China disebabkan setidaknya oleh 11 spesies Colletotrichum. Sedangkan Silva et al. (2019) mengiventarisir ada 24 spesies Colletotrichum di Asia termasuk dari Indonesia ada 7 spesies Identifikasi yang tepat dari patogen ini penting untuk mengurangi risiko masuknya patogen baru yang jika terjadi dapat berdampak buruk bagi industri lokal. Selain itu, identifikasi spesies yang akurat penting untuk program pemuliaan ketahanan dan dalam mengidentifikasi kisaran spesies inang.

Penelitian ini bertujuan untuk memetakan sebaran penyakit antraknosa pada pertanaman cabai di lahan rawa lebak dan rawa pasang surut, serta mengidentifikasi patogen penyebab penyakit antraknosa di daerah tersebut.

\section{METODE PENELITIAN}

\section{Survei penyebaran penyakit Antraknosa pada cabai di lahan rawa}

Untuk mengetahui penyebaran penyakit antraknosa pada pertanaman cabai dilakukan pengamatan di sentra pertanaman lahan rawa lebak di desa Hiyung Kabupaten Tapin dan di lahan rawa pasang surut desa Karya Maju Kecamatan Marabahan Kabupaten Barito Kuala. Metoda yang digunakan adalah metode survey dan pengambilan sampel berdasarkan Purpossive Random Sampling. Dipilih lahan yang ditanami cabai, kemudian dipilih lahan cabai yang sedang berbuah karena penyakit ini menyerang buah cabai . Di lahan rawa lebak desa Hiyung ada 20 lahan pertanaman cabai rawit Hiyung yang sedang berbuah Di lahan rawa pasang surut kecamatan Marabahan ada 24 lokasi yang terdapat di empat desa yang tanaman cabainya sedang berbuah yaitu Desa Karya maju, desa Antar Raya, desa Antar Baru, Desa Sidomulyo. Di lokasi ini petani menanam tiga jenis cabai yaitu cabai besar dan cabai keriting, maupun cabai rawit. Cabai rawit yang ditanam juga bermacam macam yaitu cabai rawit japlak, cabai rawit taji dan rawit putih. Masing masing lokasi diamati 5 tanaman sampel. Perhitungan kejadian penyakit dengan rumus

\section{$\mathrm{KP}=\mathrm{n} / \mathrm{N} \times 100 \%$}

$\mathrm{KP}=$ kejadian penyakit, $\mathrm{n}=$ buah terserang, $\mathrm{N}=$ jumlah buah total 
Untuk identifikasi patogen, sampel tanaman diambil dari lokasi survei berupa tanaman bergejala antraknosa $\mathrm{Pa}$ togen penyebab penyakit ditentukan dengan Postulat Koch. Untuk memenuhi Postulat Koch, gejala yang berkembang pada buah yang diinokulasi dibandingkan dengan gejala aslinya dan jamur diisolasi kembali dari buah yang diinokulasi. (Oo et al., 2017). Langkah awal dalam mengidentifikasi jamur dengan postulat Koch adalah pengamatan secara langsung bagian tanaman yang bergejala, baik yang masih segar tanaman yang sehat maupun yang telah bergejala. Deskripsi gejala meliputi bentuk warna tekstur bau dan parameter lainnya yang mendukung. Pembuktian bahwa pada buah yang bergejala antraknosa terdapat pathogen Colletotrichum, maka dilakukan isolasi dengan menumbuhkan potong buah bergejala pada media PDA pada media PDA. Isolat murni pathogen hasil isolasi dari buah cabai hiyung yang bergejala dilakukan inokulasi ke buah cabai sehat. Isolat yang terbukti mampu menimbulkan gejala serupa dengan gejala awal dilakukan isolasi kembali untuk dipelajari morfologi miselium, sporanya seperti; warna, bentuk, dan ukurannya. Saat uji postulat Koch ini juga dilakukan pengamatan masa inkubasi dan tahapan perkembangan gejala. Isolat yang mampu memenuhi prosedur postulat Koch dan terpendek masa inkubasinya dilakukan identifikasi berdasarkan kunci determinasi; Selanjutnya isolat terpilih dilakukan perbanyakan dalam tabung biakan miring dan dilakukan pengamatan morfologi koloni secara teliti dengan pengamatan secara langsung dengan mengamati morfologi koloni dan tidak langsung dengan bantuan mikroskop untuk mengamati morfologi mikroskopik jamur Colletotrichum $s p$ yaitu konidia, konidiofor, seta, sporodochia, dan komponen lain yang mendukung. Identifikasi penyebab penyakit mengikuti kajian literatur yaitu Liu et al.(2016), Weir et al. (2012), Silva et al. (2019), Mongkolporn et al. (2010), Damm et al. (2009), Förster \& Adaskaveg (1999), Adaskave \& Förster (2000), Damm et al (2012).

\section{HASIL DAN PEMBAHASAN}

Di lahan rawa lebak desa Hiyung dipilih 20 lahan cabai rawit Hiyung yang sedang berbuah. Sedangkan di lahan pasang surut ada 4 desa yang terdiri dari 41 lahan pertanaman cabai dan dipilih 20 lokasi yang sedang berbuah. Semuanya (100\%) lokasi survei tersebut terserang penyakit antraknosa, dengan tingkat kejadian penyakit yang berbeda beda. Hasil pengamatan kejadian penyakit antraknosa pada pertanaman cabai di lokasi sampel di lahan rawa lebak (Gambar 1) dan pasang surut (Gambar 2) dengan rata-rata kejadian penyakit masing masing $45.59 \%$ di desa Hiyung dan 57.54\% di Kecamatan Marabahan.

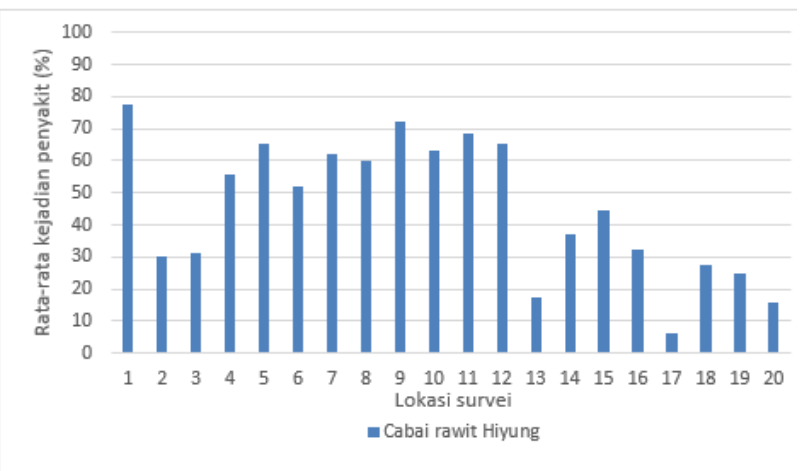

Gambar 1. Rata rata kejadian penyakit antraknosa pada cabai Hixung di lahan rawa lebak Desa Hixung

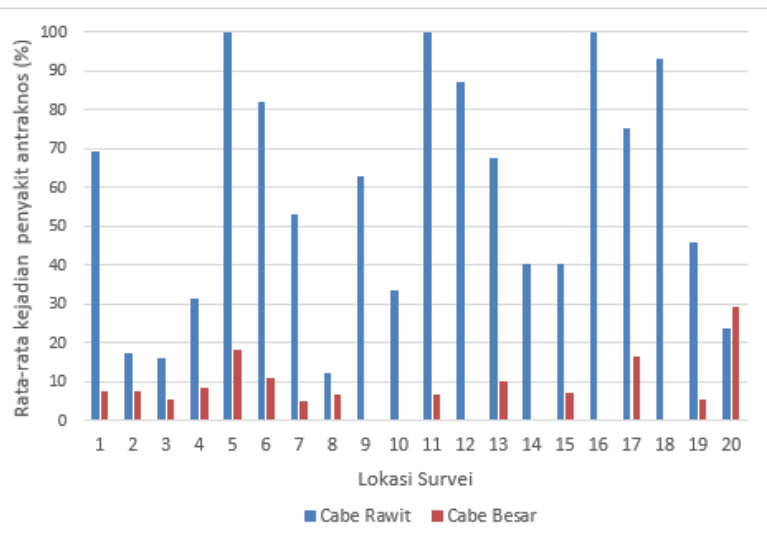

Gambar 2. Rata rata kejadian penyalit antraknosa di lahan rawa pasang surut di Kecamatan Marabahanl

Rata rata kejadian penyakit di lahan pasang surut Kecamatan Marabahan sedikit lebih tinggi dari pada di rawa lebak di desa Hiyung, dan distribusinya tidak merata. Ada tiga lokasi di Marabahan yang kejadian penyakitnya $100 \%$ artinya seluruh buah cabai di lokasi tersebut terserang penyakit antraknosa. Hal ini. menyebabkan petani memusnahkan tanamannya. Di lain fihak beberapa lokasi kejadian penyakitnya rendah terutama di lokasi yang tanaman cabai ditanam di antara kelapa sawit. Cabai yang ditanam di lahan pasang surut Marabahan terdiri atas cabai merah dan cabai rawit. Berbeda dengan kondisi pertanaman cabai di lahan rawa lebak desa Hiyung. Penyakit antraknosa di sentra pertanaman cabai rawit banjar Desa Hiyung sudah mulai terdeteksi pada tahun 2015 (Budi \& Mariana, 2016) namun belum menjadi masalah bagi petani, Pada tahun 2019 penyakit ini menjadi masalah utama dan memiliki potensi untuk berkembang lebih tinggi. Di desa ini tanaman cabai ditanam sepanjang musim, sehingga inang terus tersedia. Hal ini disebabkan pada lahan rawa lebak Desa Hiyung, cabai rawit ditanam di atas tukungan dengan sistem surjan. Sehingga cabai bisa ditanam sepanjang musim baik musim hujan maupun kemarau. Pada musim hujan walaun daerah sekitarnya tergenang air tetapi tanaman cabai di 
atas tukungan masih dapat tumbuh. Sedangkan pada musim kemarau bagian bawahnya masih tersedia air tanahnya.

\section{Identifikasi patogen antraknosa cabai}

Berdasarkan gejala, terdapat tiga jenis gejala antraknosa yaitu dua jenis gejala terdapat di desa Hiyung yang diidentifikasi sebagai C. gleosporiodes dan $C$. truncatum. Jenis lainnya terdapat di Kecamatan Marabahan yang diidentifikasi sebagai C. acutatum.

Gejala yang terdapat di desa Hiyung diawali dengan terbentuknya lekukan kemudian muncul bercak berwarna abu abu tua sampai hitam. Di bagian tengah gejala terdapat bintik bintik kecil yang berwarna kehitam-hitaman. Serangan lebih lanjut mengakibatkan buah mengkerut, kering dan membusuk. Bercak dikelilingi oleh pinggiran yang berwarna coklat (Gambar 3a). Koloni jamur hasil isolasi dari gejala tersebut berwarna putih yang lama kelamaan akan menjadi abu abu muda pada bagian tengah media terdapat bulatan bulatan kecil acervuli berwarna hitam yang tersebar pada bagian koloni yang lebih tua (bagian tengah kultur) terdapat miselium udara. Pertumbuhan koloni cepat dalam waktu 6 sampai 7 hari sudah mencapai $90 \mathrm{~mm}$. Miselium udara seperti kapas atau kapas yang padat (Gambar 3b). Pengamatan mikroskopik menunjukkan konidia tumbuh dari konidiofor yang terdapat pada acervuli (Gambar $3 \mathrm{c}$ dan $3 \mathrm{~d}$ ). Konidia berbentuk silinder, lurus dengan kedua ujung yang tumpul (Gambar 3e). Berdasarkan deskripsi gejala oleh Liu et al. (2016) gejala Hiyung I merupakan gejala tipe I yaitu gejala berwarna coklat tua sampai hitam, bercak cekung dengan banyak acervuli hitam di permukaan, massa konidia berwarma putih kotor yang banyak dalam kondisi lembab. Berbeda dengan hasil pengamatan Liu et al.(2006) yang menyebutkan bahwa konidia yang dihasilkan oleh gejala tersebut berbentuk sabit, sedangkan hasil pengamatan pada penelitian ini konidia berbentuk silinder, kedua ujungnya tumpul. Hal ini sesuai dengan pendapat Weir et al. (2012) yang menghubungkan antara karakter koloni dengan morfologi konidia untuk C. gloeosporiodes kompleks. Koloni tumbuh lebih cepat pada PDA mencapai diameter $85 \mathrm{~mm}$ setelah 10 hari. Koloni sering kali pada bagian pinggir seperti kapas, miselium udara abu-abu dengan banyak acervuli berbasis gelap dan cairan konidial oranye terlihat melalui miselium; bagian tengah miselium padat, kapas hingga terasa, lebih sedikit acervuli dan ini tersembunyi oleh miselium padat. Pada sebalik cawan Petri, bercak abu-abu gelap tidak teratur dan menutupi pigmentasi berwarna oranye pucat.

Hasil isolasi dari cabai besar di lahan pasang surut menunjukkan bahwa gejala berwarna coklat sampai hitam baik pada cabai merah maupun cabai hijau (Gambar 4a). Seta banyak mempunyai ujung yang terpotong berwarna coklat sampai coklat tua (Gambar 4b). Koloni berwarna abu-abu muda dengan sebaliknya agak jingga dengan acervuli yang tersebar merata namun ukurannya lebih kecil daripada C. gloeosporioides (Gambar 4c). Konidia berbentuk silinder tapi panjang, Konidia tidak lurus, agak bengkok dengan ujung ujung yang membulat (Gambar 4d). Ujung yang membulat merupakan ciri dari C. gloeosporioides, sedangkan karakter konidia yang agak melengkung seperti sabit (falcate). Pada hasil inokulasi Kembali pada buah cabai sehat selain ditemukan konidia dengan ujung membulat juga ditemukan konidia dengan ujung lancip dengan granula di dalam selnya (Gambar 4e) ini merupakan salah satu ciri C.truncatum Hal ini sesuai dengan pendapat dari Silva et al. (2019) Hasil analisis genetic dari konidia yang berbentuk falcate dengan banyak seta adalah C. truncatum. Konidia tersebut antara lain berasal dari Indonesia, Thailand, Malaysia dan Sri Lanka. Isolat dengan konidia falcate diidentifikasi sebagai C. truncatum. Spesies ini mendominasi penyebab penyakit antraknosa cabai di Asia, 44\% (dari 260 isolat ada 115 isolat) sedangkan $56 \%$ dengan konidia lurus adalah C. gloeosporioides, C. acutatum, boninense and orchidearum species complexes. Mongkolporn et al. (2010) mengidentifikasi patotipe $C$. truncatum, C. scovillei (sebagai C. acutatum) dan C. siamense (sebagai $C$. gloeosporioides) Untuk konidia yang melengkung Damm et al. (2009) menunjukkan bahwa strain $C$. truncatum memiliki strain dengan banyak inang yang berbeda yang didominasi oleh Fabaceae dan Capsicum spp. Hasil identifikasinya menunjukkan bahwa isolate tersebut berdasarkan inangnya adalah C. dematium, C. capsici (termasuk strain epitype), C. truncatum, C. curvatum (bahan asli). Namun filogeni gen tunggal, tidak ada konsistensi dalam subkelompok yang akan mendukung pembedaan lebih lanjut taksa dalam subkelas ini. Dengan demikian, penamaan berkaitan dengan inangnya maka $C$. truncatum pada penelitian ini adalah $C$. capsica

Gejala kedua yang terdapat pada cabai rawit Hiyung adalah bercak berwarna coklat muda sampai coklat tua. Ada lekukan di permukaan bercak seperti sisik.(Gambar 5a) Apabila diamati lebih detil seperti jaringan yang bagian dalamnya hilang sedangkan bagian luarnya tetap utuh, busuk kering, mengkerut (Gambar 5 b). Hasil isolasinya menunjukkan koloni berwarna putih, kemudian akan menjadi jingga muda, pinggiran koloni tidak teratur, konsentris. Pertumbuhan lambat $54-56 \mathrm{~mm}$ dalam 10 hari (Gambar 5c). Sel konidiogenesis hialin, bersekat, tumbuh langsung dari hifa. (Gambar 5d). 


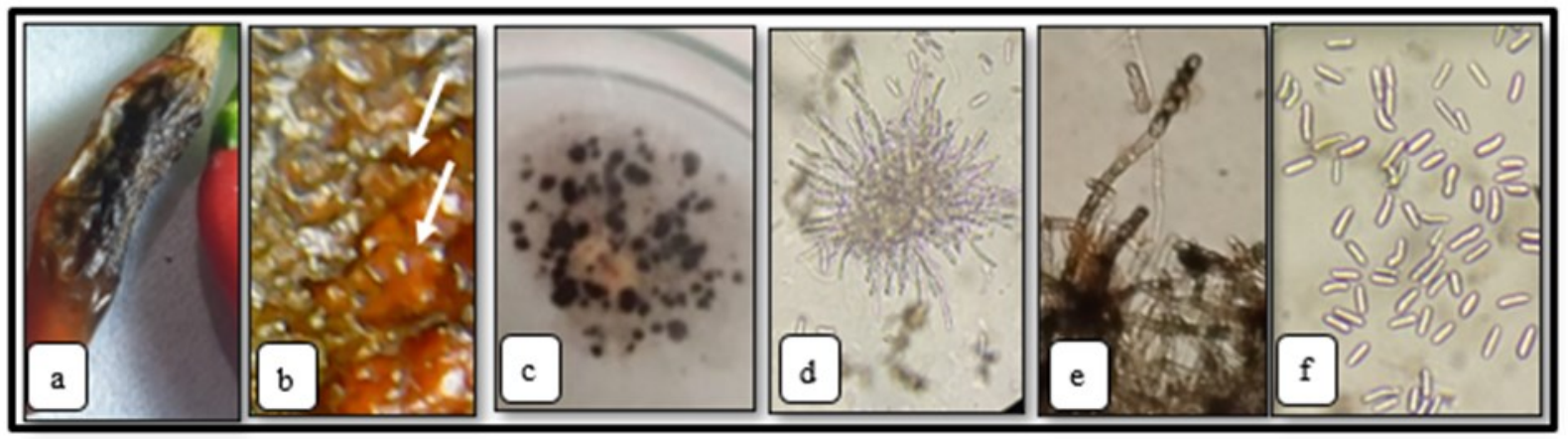

Gambar 3. C. gloeosporioides pada cabai rawit hivung asal lahan rawa lebak. a. Morfologi gejala, dan b. konidia pada permukaan buah cabai (panah). c. koloni d. acervuli dan e. konidiogenesis, dan f. konidia pada kultur media PDA,

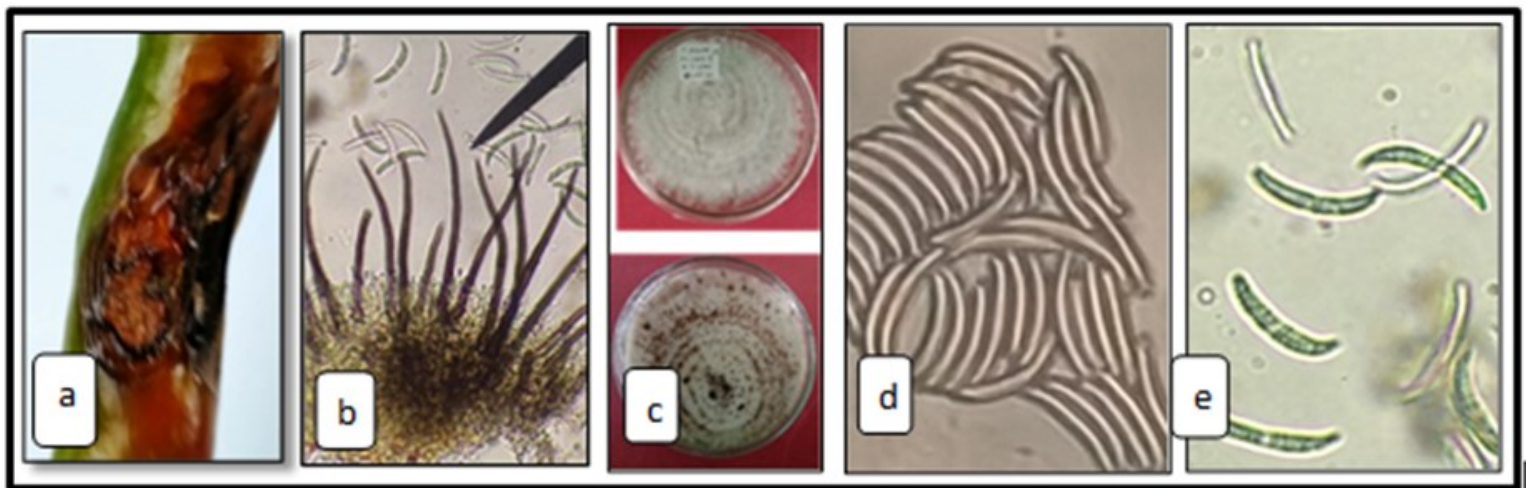

Gambar 4. C. truncatum asal lahan rawa pasang surut. a. Morfologi geiala, b. seta, c. koloni d. konidia melengkung dengan ujung tumpul dan $\mathrm{e}$, konidia melengkung dengan ujung lancip dan ada granula di dalam sel.

Konidia berbentuk lurus, fusiform dengan kedua ujungnya atau salah satunya lancip. Kadang kadang ada granul di dalam konidia (Gambar 5d).

Karakter dari hasil pengamatan gejala, kultur koloni, konidia dan konidiogenesis menunjukkan bahwa pathogen penyebab gejala hiyung kedua ini adalah C. acutatum. Hal ini sejalan dengan pendapat Förster \& Adaskaveg (1999) dan Adaskave \& Förster (2000) memasukkan morfologi kultur, dan ukuran dan bentuk konidium dalam perbandingan strain $C$. acutatum. Isolates masing-masing spesies dapat dibedakan berdasarkan bentuk konidium ketika kultur ditanam pada agar dekstrosa kentang (konidia dengan ujung bulat diidentifikasi sebagai $C$. gloeosporioides dan konidia dengan ujung runcing sebagai $C$. acutatum).

Pada agar-agar jerami kacang ukuran konidial kedua spesies saling tumpang tindih, menunjukkan bahwa karakter ini tidak dapat diandalkan untuk membedakan kedua spesies. Karakter lain yang sering digunakan untuk deskripsi isolat adalah morfologi koloni. Koloni C. gloeosporioides biasanya berwarna abu-abu sedangkan koloni $C$. acutatum berwarna merah jambu atau jingga. Namun Förster \& Adaskaveg (1999) menemukan bahwa isolat al- mond $C$. acutatum memiliki dua fenotipe yang berbeda, satu abu-abu dan satu merah muda, dan oleh karena itu perlu banyak kehati-hatian saat menggunakan karakter ini untuk pemisahan spesies. Karakter lain, bagaimanapun, telah membantu untuk pemisahan isolat $C$. acutatum dari $C$. gloeosporioides, misalnya. tingkat pertumbuhan (lambat, di $C$. acutatum dan cepat di $C$. gloeosporioides).

Identifikasi ini juga diperkuat oleh Wharton \& Uribeondo (2004) bahwa C. acutatum mempunyai karakter yaitu Konidiofor hialin, berdinding halus, kebanyakan sederhana, kadang-kadang bercabang. Sel konidiogen hialin, berdinding halus, silindris hingga sedikit menggembung. Berdasarkan panduan Damm et al. (2012) Colletotrichum ini mengarah ke C. acutatum spesies kompleks. Menurut Weir et al. (2012) beberapa penulis telah mengidentifikasi dengan PCR untuk membedakan anggota C. gloeosporioides spesies kompleks dari anggota $C$. acutatum spesies kompleks. Beberapa anggota $C$. acutatum spesies kompleks memiliki konidia tanpa ujung lancip yang merupakan karakteristik spesies ini seperti yang dijelaskan oleh Simmonds (1965), dan kadang-kadang disalahartikan dengan $C$. gloeosporioides (Damm et al., 2012). 


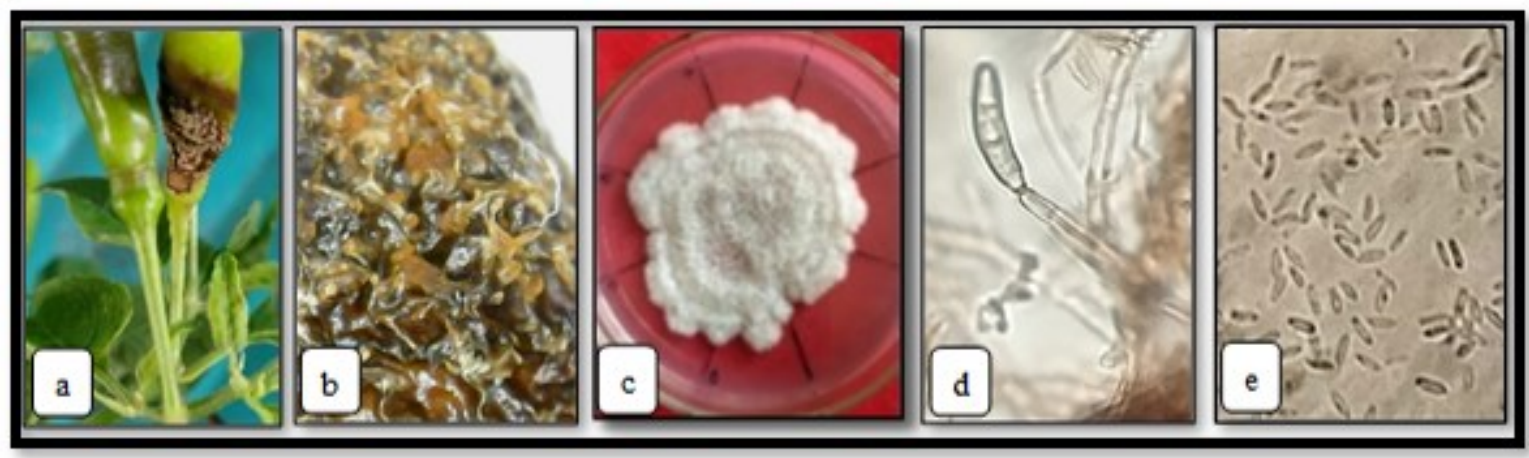

Gambar 5. C. acutatum pada cabai rawit hivung asal lahan rawa lebak. a. Morfologi gejala, dan b. detil gejala busuk kering dan mengkerut pada permukaan buah. c. koloni d. konidiogenesis yang muncul dari hifa dan e. konidia pada kultur media PDA,

\section{KESIMPULAN}

Penyakit antraknosa terdapat di semua lahan rawa. Rata rata kejadian penyakit di lahan rawa lebak Desa Hiyung 43,78 \%, dan di lahan rawa pasang surut Kecamatan Marabahan 57.54\%

Patogen penyebab antraknosa dari lahan rawa adalah jamur genus Colletotrichum sp.. Ada tiga spesies Colletotrichum yaitu C. acutatum kompleks, $C$. gloeosporioides dan C. truncatum.

\section{SANWACANA}

Ucapan terima kasih disampaikaan kepada DIPA Universitas Lambung Mangkurat yang telah membiayai penelitian ini melalui Program Dosen Wajib Meneliti tahun anggaran 2020.

\section{DAFTAR PUSTAKA}

Adaskave, J. E. \& H. Förster. (2000). Occurrence and management of anthracnose epidemics caused by Colletotrichum species on tree fruit crops in California. In: Prusky, D.; Freeman, S.; Dickman, M.B. (Eds.). Colletotrichum: Host specificity, Pathology and Host-pathogen interaction. pp.317-336. St. Paul: APS Press.

Budi, I.S. \& Mariana. (2016) . Controlling Anthracnose Disease of Locally Chili in Marginal Wetland using Endophytic Indigenous Microbes and Kalakai (Stenochlaena palustris) Leaf Extract Journal of Wetlands Environmental Management 4 (1), $28-34$.

Damm, U., P.F. Cannon. J.H.C. Woudenberg \& P.W. Crous. (2009). Colletotrichum species with curved conidia from herbaceous hosts. Fungal Diversity 39, 45-8.

Damm, U., Cannon, P.F., Woudenberg, J.H.C., Johnston, P.R., Weir, B.S., Tan, Y.P., Shivas, R.G. \& P.W. Crous. (2012). The Colletotrichum boninense species complex. Studies in Mycology $73: 1-36$.
Damm, U., Cannon, P.F., Woudenberg, J.H.C.\& Crous, P.W. (2012). The Colletotrichum acutatum species complex. Studies in Mycology 73, 37-113.

Diao Y.Z, Zhang, C., Liu, F., Wang, W.Z., L. Liu, L. Cai, L. \& Liu, X.L. (2017). Colletotrichum species causing anthracnose disease of chili in China. Persoonia. 38, 20-37. DOI: https:// 10.3767/003158517X692788.

Förster, H. \& J.E. Adaskaveg.. (1999). Identification of subpopulations of Colletotrichum acutatum and epidemiology of almond anthracnose in California. Phytopathology 89, 1056-1065.

Kang, B.K., J.H. Kim, K.H.Lee, S.C. Lim, J.J Ji,., J.W. Lee \& H.T. Kim. (2009). Effects of Temperature and Moisture on the Survival of Colletotrichum acutatum, the Causal Agent of Pepper Anthracnose in Soil and Pepper Fruit Debris. The Plant Pathology Journal. 25 (2), 128135.

Liu F., Tang, G., Zheng, X., Li, Y, Sun, X., Qi X., Zhou, Y, Xu J., Chen H., Chang X., Zhang S . Gong G,. (2016). Molecular and phenotypic characterization of Colletotrichum species associated with anthracnose disease in peppers from Sichuan Province, China. Scientific Reports 6,32761. DOI: https://10.1038/srep32761.

Oo , M., M., GiTaek Lim G.T., Hyun A Jang, H.A. \& Oh, SK. (2017). Characterization and Pathogenicity of New Record of Anthracnose on Various Chili Varieties Caused by Colletotrichum scovillei in Korea. Mycobiology. 45 (3), 184-191

Mongkolporn, O., P. Montri, T. Supakaew \& P.W.J. Taylor. (2010). Differential reactions on mature green and ripe chili fruit infected by three Colletotrichum spp. Plant Dis. 94, 306-310.

Rajasab, A. H. \& Chawda, H.T. (1994). Dispersal of the conidia of Colletotrichum gloeosporioides by rain and the development of anthracnose on onion. Grana 33(3), 162-165, DOI: https://10. 1080/00173139409428994.

Saxena A, Raghuwanshi, R. \& H.B. Singh. (2014). Molecular, phenotypic and pathogenic variabil- 
ity in Colletotrichum isolates of subtropical region in north-eastern India, causing fruit rot of chillies Journal of Applied Microbiology 117, 1422-1434.

Saxena A, Raghuwanshi, R., Gupta, V.K. \& Singh, H.B. (2016). Chilli Anthracnose: The Epidemiology and Management. Front Microbiol. 7, 1527. DOI: https://10.3389/fmicb.2016.01527.

Semangun, H. (2007). Penyakit-Penyakit Tanaman Hortikultura di Indonesia. Gadjah Mada University Press., Yogyakarta.

Silva, D.D., Groenewald, J.Z., Crous, P.W. Peter, K. A., Nasruddin, A., Mongkolporn, O. \& Taylor, P.W.J. (2019). Identification, prevalence and pathogenicity of Colletotrichum species causing anthracnose of Capsicum annuum in Asia. IMA Fungus 10(8),2-32 DOI: https://10. 1186/ s43008-019-0001-y.

Simmonds, J.H. (1965). A study of the species of Colletotrichum causing ripe fruit rots in Queensland. Queensland Journal of Agricultural and Animal Science 22, 437-459

Singh, A.K. \& Pandey, A.K. (2014). Dynamics of
Anthracnose Disease of Chilli in Responses to Water and Nitrogen Management under Drip and Flood Irrigation. Journal of AgriSearch 1(3), $151-156$

Soesanto, L. (2019). Kompedium Penyakit Penyakit Cabai. Andi Offset. Yogyakarta

Than P.P., Prihastuti, H., Phoulivong, S., Taylor, P.W. \& H.D. Hyde. (2008). Chilli anthracnose disease caused by Colletotrichum species. J. Zhejiang Univ.Sci.B.9(10):764-778. DOI: https://10.1631/ jzus.B0860007.

Wharton P. S. \& Uribeondo, J.D. (2004). The biology of Colletotrichum acutatum. Anales del Jardin Botánico de Madrid, 61(1), 3-22.

Weir, B.S , Johnston, P.R.\& Damm, U. (2012). The Colletotrichum gloeosporioides species complex. . Studies in Mycology 73, 115-180.

Widodo \& Hidayat, S.H. (2018). Identification of Colletotrichum Species Associated with Chili Anthracnose in Indonesia by Morphological Characteristics and Species-Specific Primers. Asian Journal of Plant Pathology 12 (1), 7-15. DOI: https://10.3923/ajppaj.2018.7.15. 